\title{
WHO IS MORE EAGER TO LEAVE? DIFFERENCES IN EMIGRATION INTENTIONS AMONG LATVIAN AND RUSSIAN SPEAKING SCHOOL GRADUATES IN LATVIA
}

\author{
Zane Varpina \\ Stockholm School of Economics, \\ Baltic International Centre for Economic Policy Studies, Latvia \\ Kata Fredheim \\ Stockholm School of Economics, \\ Baltic International Centre for Economic Policy Studies, Latvia \\ Marija Krumina \\ Baltic International Centre for Economic Policy Studies, Latvia
}

\begin{abstract}
Data on migration flows suggest that young people are highly mobile. Yet, there are gaps in the evidence concerning the factors driving young people's international migration in Latvia. Latvia is a potentially interesting case because of the high rate of migration from the country, but also because it is a complex ethnic and linguistic environment. Latvian and Russian speaking populations are shown to have diverse migration drivers, and this study addresses the differences in attitudes to studying and living abroad for adolescents at the time of school graduation. Literature suggests that Russian-speaking population have higher propensity to emigrate. We aim to contribute to the literature by exploring differences in migration intentions between Latvian and Russian speaking high school graduates.

This study is based on individual-level survey data of secondary school graduates in Latvia in 2020, amidst COVID-19 pandemic. We analyse the strength of migration intentions from definitely not leaving Latvia to surely planning to emigrate. We conclude that Russian-speakers exhibit stronger intentions to emigrate compared Latvian-speaking youngsters, driven by wider networks and expected higher returns to their human capital abroad.
\end{abstract}

Keywords: Youth migration, migration intentions, adolescents, Russian-speaking minority.

\section{Introduction}

In Latvian context language - Latvian and Russian - tend to be an important parameter, dividing the population Latvian- and Russian-speaking communities. Because the collapse of the Soviet Union brought to the fore and rearranged ethnic identities and at the same time these groups have coexisted for long, creating 
Varpina et al., 2021. Who is More Eager to Leave? Differences in Emigration Intentions Among Latvian and Russian Speaking School Graduates in Latvia

mixed ethnicity and language families, ethnicity is a complex issue in Latvia. The two population groups manifest diverse behaviours also with respect to migration.

In the first two decades after the fall of the Soviet Union, the percentage of minorities, including Russians, who migrated from Latvia far exceeded the proportion of Latvians who migrated. Yet, between 2011- 2016, there has been a significant drop in migration of ethic Russians; the difference in percentage points between ethnic Russians and Latvians was only 1.7\% (Hazans, 2019).

Migration intentions saturate during the school times (Lulle and JurkaneHobein, 2017), hence in this study we focus on differences in migration intentions on the moment after school graduation that is a pivotal moment in person's life and assess willingness to study and live abroad for Latvian adolescents. We seek to learn how migration intentions differ between recent Latvian- and Russianspeaking school graduates, and aim to contribute to the literature by assessing migration intentions and differences between Latvian and Russian speakers.

\section{Background}

Research on migration flows by age group suggest that youth is highly mobile - in Europe people aged 15-29 were by far the most mobile population group during the period 2013-2017, with mobility peaking at the age of 25-29. Yet, despite the fact that young people account for the bulk of international migrant flows and they consistently show stronger migration intentions than the rest of population, there are gaps in the evidence concerning the factors driving young people's international migration.

A relatively recent strand of research has tried to overcome this limitation by focusing on the drivers of potential migration rather than on actual migration. In recent years there has been growing interest from academic community in studying intentions to migrate, determinants and consequences (Migali and Scipioni, 2019; Esipova et al, 2016). Exploring the drivers of potential migration, though relevant in its own right, may help to better understand the factors that shape youth's actual migration behaviour. Even if choices and circumstances for young adults often change over time, it is important to analyse the migration intentions. Intentions to migrate do not necessarily translate into actual migration behaviour, but they are often driven by the same factors that trigger actual migration and can, therefore, represent a good predictor of actual emigration trends in the future. Aspirations and desires to migrate have been shown to be powerful determinants of actual mobility from as early as Ajzen et al. (1980) and De Jong et al. (1985), and later studies (for example, Bradley, 2014). Plentiful of recent studies engage in analysing "potential migration" instead of actual 
migration patterns (Williams, 2018; Mintchev et al., 2017; Milasi, 2020; Dao et al., 2018 to name a few).

Part of the reason for this interest is that when the individuals have emigrated, i.e., post factum, they are difficult to reach and hence seldom anything is known about the subjective reasons and motivations of the persons to take the mobility steps. Especially if the inquiry is from the sending country point of view that might be interested in retaining the population, post-emigration research is too late to act upon, hence population surveys to study aspirations are crucial. As put by Plopeanu (2019): "In the context of insufficient or even no data regarding migration flows outside the country of origin, the data obtained through surveys on emigration intentions as proxies are extremely important for national decision makers”. Hence, from a policy perspective, exploring the migration incentives of those still residing in country of origin is just as important as investigating migration motives of people who already moved. Moreover, as data on migration intention are collected from the sending country, they are not affected by selfselection bias that allows having a broader picture of the propensity to migrate across different socioeconomic groups. Against this background, research on youth potential migration has grown in recent years, pointing to a wide range of demographic, socioeconomic, institutional, and contextual drivers of migration intention among young people.

A number of cross-country studies have addressed migration intentions in Latvia. Williams et al. (2018) studied one- and five-year migration intentions of young population in nine European countries, including Latvia, based on Eurobarometer data. They found that prior migration experience, weak status of economy, manual work and researched migration opportunities were four top factors contributing positively to intentions to migrate. Otrachshenko and Popova (2014) studied the impact of life satisfaction on migration intentions and found that Latvia, being among countries with relatively low level of life satisfaction, is associated with high emigration intentions. A further study by Van Mol (2016) that is based on Eurobarometer data for CEE and includes Latvia reveals the importance of individual factors and feelings of discontent among key drivers of youth migration intentions. Yet another cross-country study that covers Latvia among other 138 countries by Docquier et al. (2014) was based on World Gallup survey data on potential migrants. The emphasize the role of networks in migration intentions.

Separately for Latvia, actual migration flows across and within borders have been widely studied. Recent findings on emigration and the emigrant life abroad have been summarised in the book "The emigrant communities of Latvia" (eds. Kasa and Mierina, 2019). The profile and trajectories of Latvian external migrants has been analysed by McCollum, Apsite-Berina, Berzins and Krisjane (2017), internally by Apsite-Berina, Burgmanis and Krisjane (2019). On the other hand, 
Varpina et al., 2021. Who is More Eager to Leave? Differences in Emigration Intentions Among Latvian and Russian Speaking School Graduates in Latvia

migration intentions with regards to youngsters and ethnic aspects, have not been scrutinised.

Latvia has a large share or Russian-speaking minority - in 2021 it accounts for $41 \%$ of the population. After the fall of the USSR, many Russian speakers felt more like Soviet citizens than Russian (Vihalemm and Masso, 2003; Linz and Stepan, 1996). These weak collective identities later consolidated around language, into Russian-speaking minorities (Laitin, 1995; Melvin, 1995) and thus remain substantially different from the identities of Russians in Russia (Zepa, 2006; Vihalemm \& Masso, 2003; Cheskin, 2013). Complex issues remain around Russian-speakers integration in Latvia. Russian speakers would like to integrate rather than assimilate; they both want to learn Latvian language and culture and maintaining their cultural and linguistic identities (Kronenfeld, 2005; Pisarenko, 2006; Sūpule, 2007). As a result, Russian-speakers often observe different customs and behaviours; Russians are less involved in celebrating Latvian state holidays (Zelče, 2018). Russian speakers commonly consume different media, often from Russia (Ikstens, 2018) and express weaker sense of belonging to the state (Muižnieks, Rozenvalds and Birka, 2013).

That is not to say that Latvian and Russian speaking populations do not inhabit separate social and economic spaces in most of the country. Almost all (94\%) Russian native speakers speak at least basic Latvian, 51\% of Russian younger generation (18-34) speak good or very good Latvian (Latviešu valodas aǵentūra, 2020). The majority (61\%) of Latvian residents who speak primarily Russian at home feel proud to live in Latvia (Berzina, 2018). Furthermore, Latvian and Russian speakers interact on an everyday basis, at least 75-90 per cent of nonLatvian speakers have a Latvian friend or colleague (Eesti Koostöö Kogu, 2011).

The two population groups demonstrate different migration patterns too. In 1990s and 2000s, ethnic Russian's migration has been significantly higher than that of Latvians. In the decade after the collapse of the Soviet Union, migration of all minority groups was high, Russians included (18\%, according to the Census). Hazans (2016) finds that Russian-speaking population in pre-EU accession time had lower labour market outcomes and hence contained greater emigration potential which materialised in overrepresentation of Russian-speakers among emigrants. While in the 2000s migration of ethnic Russians was double that of Latvians (-11.8\%); between 2011-16 the numbers almost converged: the difference was only 1.7 percdentage points (Hazans, 2019). With respect to emigration reasons in ethno-linguistic context, Lulle and Jurkane-Hobein (2016), who interviewed Russian-speaking migrants from Latvia to London, illuminated the crucial role of power positions of being a 'stranger within' on migration decisions. Ivlevs (2013) concluded that minorities are more eager to emigrate than 
the majority because of disadvantageous linguistic and citizenship policies, family migration capital and the way minority education is provided.

Lulle et al. (2016) notes that the idea of departure saturates already during school. However, to date, as far as our knowledge goes, there are no studies documenting youth emigration or migration intentions in Latvia from ethnic or linguistic perspective. We aim to close the gap by reporting results from secondary school graduate study. We hypothesize, based on the overall sentiment and previous studies, that Russian-speaking youngsters are more eager to study abroad and emigrate to live abroad.

\section{Methodology}

This study adopts a mixed-method approach of survey research combined with qualitative interviews to address the research question and explore differences in Latvian and Russian speaking graduate sentiment with respect to study plans and migration intentions.

We point our attention to two indicators of intended migration. First of all, for those respondents that intend to start studies in the year of secondary school graduation, we ask where she intends to do so - Latvia, or abroad, and if the answer is abroad - the respondent is asked to specify the target country. Second, we ask all respondents if they intend to live abroad for some period of their life, offering answer options in Likert scale with the following anchors: 'Definitely yes', 'Probably yes', 'Might or might not', 'Probably not' and 'Definitely not'. Purposefully, we chose to ask widely without specifying time limit. We realise that youngsters at the age of 18 and 19 are not able to plan the life in advance very well, and if they can, the plans are commonly not time-bound. From our perspective, it was important to record the sentiment and attitude towards life abroad. Similar approach - vague time frame - has been used in a number of other studies, for example Van Dalen and Henkens (2012) ask 'Do you expect to work abroad for a couple of years in the next 10 years?'; Cairns (2014) for the Ireland study: 'In the future, I see myself always living in Northern Ireland/Republic of Ireland.' (Yes'/'No'); Flash Eurobarometer 395 survey: 'You want to study, undergo training or work in another EU country than [your own]' = 'Yes'/ 'No'.

Respondents were able to indicate their native language with possible options 'Latvian', 'Russian' and 'other'. The respondents could select multiple replies yielding a category "mixed" in the results. It was decided against asking for the ethnicity directly as we reasoned it would be too confusing and time consuming for a youngster to answer, and ease of answering was prioritised not to lose the attention of the respondents.

We run a survey for Latvian secondary school graduates in 2020. It was distributed to general and professional secondary school final year pupils in April 
Varpina et al., 2021. Who is More Eager to Leave? Differences in Emigration Intentions Among Latvian and Russian Speaking School Graduates in Latvia

and May 2020. The moment for fieldwork was chosen bearing in mind that it is the last period of time when all the graduate cohort can be met together. After the end of the school year graduates leave schools and do not come together again. Also for online surveys there is no common platform to reach out to all graduates of the cohort, making the period of 1-2 months to end of the year the closest to graduation moment for survey. Running the fieldwork even closer to the graduation is not possible, since students have final examinations, and both, the target group and the teachers, are too busy.

The letter with a request to distribute the invitation to participate in the survey to final year pupils was sent to official email addresses of a selected sample of schools in Latvia, followed by a call to school's administration. The invitation was forwarded to pupils via e-klase.lv learning platform, that all secondary schools use. The sample of schools to address was selected to be nationally representative - include all regions, urban and rural schools, different size of schools, gymnasiums and regular secondary schools, as well as Latvian and Russian language schools.

The obtained sample can be considered representative, covering the entire country, including rural areas. The original obtained sample was 1074 responses. 92 responses had to be eliminated due to being empty. We reason these may have been school teachers or administration looking through the survey before forwarding to pupils, and some curious pupils without filling the survey. 97 other responses were eliminated because respondents did not indicate their native language, the critical parameter for this study. The final sample used for analysis is 885 respondents. In addition, we perform 5 semi-structured qualitative interviews with the aim to validate and triangulate the findings of the survey.

We apply descriptive and inferential statistics methods to study differences between the population groups of interest. In particular, we use contingency tables with Chi-Square tests. Insights from in-depth interviews help to explain the findings.

\section{Results}

\section{Study intentions}

We learn that $83 \%$ of secondary school graduates in Latvia, who plan to continue education in the year following secondary school graduation, intend to study in Latvia, while $16 \%$ aim for studies abroad. However, data show that there is statistically significant relationship (Pearson Chi-Square $(6, \mathrm{~N}=885)=27.55$, $\mathrm{p}=0.000$ ) between native language and study migration plans (Table 1). $86 \%$ of Latvian-speaking, but only $73 \%$ of Russian-speaking graduates intend to stay in Latvia. We are careful to make firm conclusions about the pupils coming from 
mixed backgrounds, as there were only 30 such observations. The group contains mostly Latvian-Russian, but also other combinations of native languages.

Table 1 Study Plans in the Year Following Secondary School Graduation (\% within native language)

\begin{tabular}{|l|r|r|r|r|r|}
\hline & \multicolumn{4}{|c|}{ Native language } & \multicolumn{1}{c|}{ Total } \\
\hline Where do you plan to study? & Latvian & Russian & Mixed & Other & \\
\hline Latvia & 85.8 & 73.2 & 90.9 & 40.0 & 82.9 \\
\hline Abroad & 13.3 & 23.7 & 9.1 & 60.0 & 15.7 \\
\hline No answer & 0.9 & 3.0 & 0.0 & 0.0 & 1.4 \\
\hline Total count & $\mathbf{6 4 9}$ & $\mathbf{1 9 8}$ & 33 & $\mathbf{5}$ & $\mathbf{8 8 5}$ \\
\hline Total \% & $\mathbf{1 0 0 \%}$ & $\mathbf{1 0 0 \%}$ & $\mathbf{1 0 0 \%}$ & $\mathbf{1 0 0 \%}$ & $\mathbf{1 0 0 \%}$ \\
\hline
\end{tabular}

Source: authors' computations.

The choices of the study target countries abroad range from Europe to America, but we did not find specific patterns associated with the native language. United Kingdom takes the prominent first place - it was mentioned among targets in $18 \%$ of responses (UK alone or along with another country). Further, Denmark and the Netherlands are commonly mentioned, presumably because of wide availability of studies in English paired with no or low study fees. We also find Ireland, Sweden, Germany, Poland and Estonia among the countries of interest. A few Russian speaking respondents mentioned Russia for studies, while no Latvian-speaking respondent intends to study in the Eastern neighbour country.

\section{Migration intentions}

Looking at more general migration aspirations, we find that notable $58 \%$ of school graduates are positively minded regarding possibility to live abroad for some period of their life (Table 2). Even more, 28\% of the graduates say they definitely want to live abroad for some period, while $30 \%$ are vaguely positive. Only $14 \%$ are strongly (2\%) or probably (12\%) negative about intentions to live abroad. One third of the respondents had not made up their mind or were unsure.

Analysis by native language reveals important and statistically significant differences (as supported by Pearson Chi-Square (12, $N=885)=48.66, \mathrm{p}=0.000$ ). The Russian-speaking adolescents have significantly stronger aspirations to live abroad - 23\% of Latvian-speaking and $44 \%$ of Russian-speaking graduates 'definitely' plan to live abroad at least for some period of their life. So, overall half of Latvian-speaking (53\%), but striking three quarters of Russian-speaking minority youngsters can be considered potential migrants. 
Varpina et al., 2021. Who is More Eager to Leave? Differences in Emigration Intentions Among Latvian and Russian Speaking School Graduates in Latvia

Table 2 Migration Intentions (\% within native language)

\begin{tabular}{|l|r|r|r|r|r|}
\hline & \multicolumn{3}{|c|}{ Native language } & Total \\
\hline \begin{tabular}{l|r|r|r} 
Do you plan to live abroad for some period in the \\
future?
\end{tabular} & Latvian & Russian & Mixed & Other & \\
\hline Definitely not & 2.2 & 1.5 & 0.0 & 0.0 & 1.9 \\
\hline Probably not & 14.3 & 5.6 & 6.1 & 0.0 & 12.0 \\
\hline Might or might not & 30.8 & 19.2 & 27.3 & 0.0 & 27.9 \\
\hline Probably yes & 29.6 & 29.3 & 39.4 & 40.0 & 29.9 \\
\hline Definitely yes & 23.1 & 44.4 & 27.3 & 60.0 & 28.2 \\
\hline Total count & $\mathbf{6 4 9}$ & $\mathbf{1 9 8}$ & $\mathbf{3 3}$ & $\mathbf{5}$ & $\mathbf{8 8 5}$ \\
\hline Total \% & $\mathbf{1 0 0 \%}$ & $\mathbf{1 0 0 \%}$ & $\mathbf{1 0 0 \%}$ & $\mathbf{1 0 0 \%}$ & $\mathbf{1 0 0 \%}$ \\
\hline
\end{tabular}

Source: authors' computations. $\mathrm{N}=885$.

Scrutinising the reasons behind the willingness to live abroad (Figure 1), we find major differences for the two native language groups.

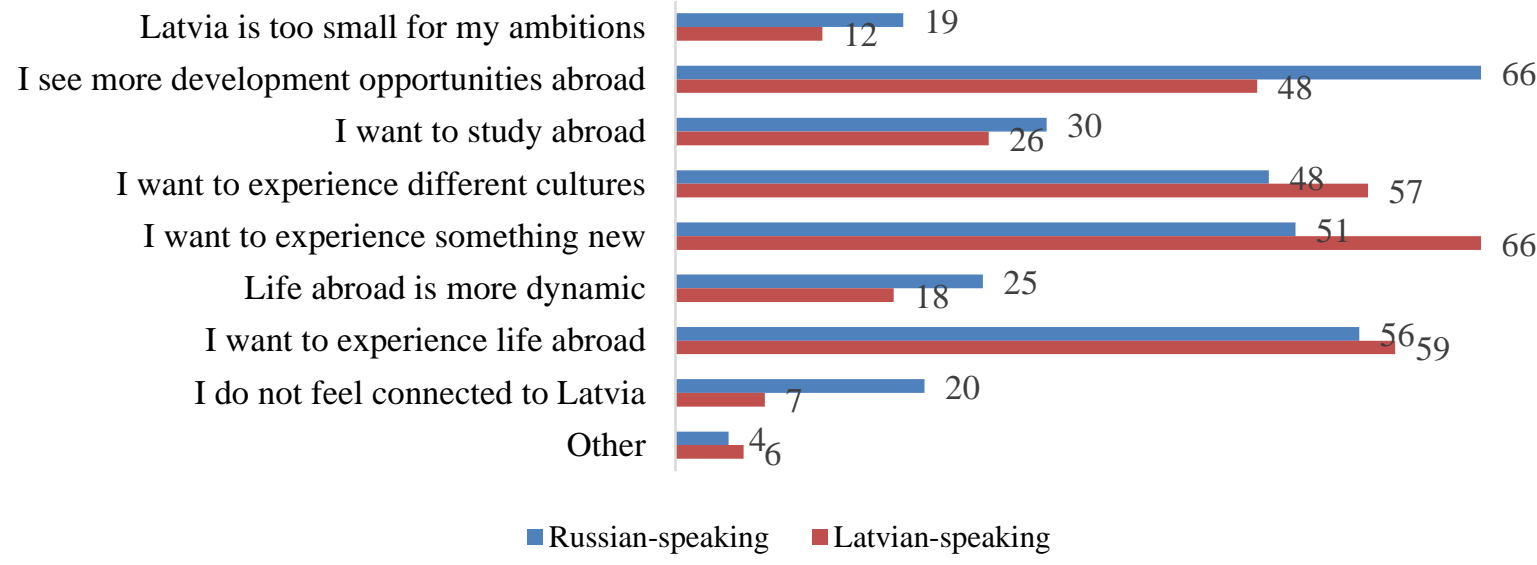

Figure 1 Reasons for Willingness to Live Abroad in the Future

(multiple answers possible, \% of respondents by native language).

Source: authors' calculations

For Latvian-speaking adolescents new general, life and cultural experiences appear to be the primary reasons that drive their interest in living abroad, while for the Russian-speaking youngsters the most common reason is the fact that they see more development opportunities abroad, followed new experiences, similar to Latvians. The feeling of disconnection from Latvia is higher for the Russianspeaking minority (20\% of respondents mention it among determinants in contrast to $7 \%$ Latvian-speakers). Also, more commonly among Russians, Latvia is perceived as being too small for one's ambitions. 


\section{Discussion}

The analysis revealed that Russian-speaking adolescents in Latvia exhibit higher migration intentions as indicated by higher aspirations to study abroad and more determined to live abroad for at least some period of their life. The results go in line with our hypothesis and previous research. The reasons for such a split can be several and are most likely interlinked, so the in-depth interviews with Russian school graduates can help to interpret them.

Russian-speaking population more commonly have ancestors in other countries, and relatives still living abroad. Aleksandrs (19, pseudonym), a Russian-speaking graduate explains: "I have thought of moving to Azerbaijan, the native country of my father, because there are, too, a lot of opportunities, if you are clever enough. I have many relatives there. My grandmother, too." Kinship and other networks are shown to be important factor in migration decisions according to migration theory, and since the size of the Russian speaking diaspora is large (estimated over 30 million) this may provide significant opportunities for youth. In addition, given the high rate of migration of Russian-speakers from Latvia in recent decades, the network of Russian speaking Latvians is significant. Future migrants may know of these networks and rely on them for inspiration and information even prior to migration. These networks provide support during the migration journey, from moving to finding a job and finding a community.

Another explanation, in particular for higher intentions to study abroad, is the study language. While most Russian speaking youth in Latvia speak at least good Latvian, Russian graduates who have acquired secondary education primarily in Russian language, may choose not to study in Latvian (most higher education programmes in Latvia). On the one hand, studying in a language different from previous education could be challenging. Studying in English could be more convenient and may be seen as more beneficial for one's future career. Indeed, research shows that return migrants may receive up to $88 \%$ wage premium if they have a master's degree from abroad (Hazans, 2017). According to our survey, Russia does not appear to be among the prime study destinations, the graduates are looking West.

The third potential reason for higher emigration desires could be less satisfaction with the environment and disconnection from the state. This explanation appears higher among the Russian-speaking respondents, but it is not among the main reasons. This narrative would be supported by Ivlevs (2013), however, we could not back this argument by information from our interviews with Russian graduates. Instead, we tend to believe that they are more open to see the wide opportunities that the world offers, reinforced by being subject to more multicultural environment. This would go in line with Lulle's et al. (2017) conclusion that Russian-speakers do not relate the future only to the Latvian 
Varpina et al., 2021. Who is More Eager to Leave? Differences in Emigration Intentions Among Latvian and Russian Speaking School Graduates in Latvia

society but "to broader European space and opportunities". One of our informants (Mihails, 19), who wants to go to Russia after studies reveals: "Well, I have this desire, which I cannot explain. To my mind, there are some wishes, which are inside us - I want it and that's it - and that means, that it is the right path to follow, but... Then again, I don't know, how I will do it there in Moscow and I don't know if I will like it there, and maybe after a year I will change my mind... (..) And at the same time, I cannot say that I have planned to stay in Latvia, me too, I plan to work abroad."

Overall, our results confirm that Russian speaking high school graduates in Latvia have higher migration intentions. From the policy perspective, exploring emigration incentives are important to study as they can help to predict mobility and possibly pro-actively influence it. If in the coming years we can expect positive youth emigration, and especially by young Russians, it would be necessary to work out solutions to make their return more attractive. Labour market benefits from the experience and skills, but not to be forgotten is also the societal and demographic benefit from more diverse and multicultural society.

\section{Acknowledgements}

This work was supported by the National Research Program Project grant number VPP-IZM-2018/1-0015 and by the Latvian Council of Science, project No. lzp-2018/1-0486.

\section{References}

Ajzen, I.; Fishbein, M. (1980). Understanding Attitudes and Predicting Social Behavior. Prentice-Hall: Upper Saddle River, NJ, USA.

Apsīte-Berinna, E., Burgmanis, G.., \& Krišjāne, Z. (2019). Exploring labour migration from Latvia: Geographies of origin. World.

Aptekar, S. (2009). "Contexts of exit in the migration of Russian speakers from the Baltic countries to Ireland". Ethnicities, 9(4), 507-526.

Bērziṇa, I. (2018). I. Bērzina (Eds.), Patriotisms Latvijas jauniešu vidū un sabiedrībā. Latvijas Nacionālā aizsardzības akadēmija. Drošības un stratęgiskās pētniecības centrs, 06/2018

Bradley, D., Longino, C.F., Stoller, E.P.; Haas, W.H. (2014). III. Actuation of mobility intentions among the young-old: An event-history analysis. Gerontologist, 48, 190-202.

Cairns, D. (2014). "I wouldn't stay here": economic crisis and youth mobility in Ireland. International Migration, 52(3), 236-249.

Cheskin, A. (2013). Exploring Russian speaking identity from below: The case of Latvia, Journal of Baltic Studies, 43(4), 283-312.

De Jong, G.F., Root, B.D., Gardner, R.W., Fawcett, J.T., Abad, R.G. (1985). Migration intentions and behavior: Decision making in a rural Philippine province. Popul. Environ, $8,41$.

Docquier, F., Peri, G., \& Ruyssen, I. (2014). The cross-country determinants of potential and actual migration. International Migration Review, 48(1_suppl), 37-99. 
Eesti Koostöö Kogu. (2011). Estonian Human Development Report 2010/11: Baltic Way(s) of Human Development: Twenty Years On.

Esipova, N., Srinivasan, R., \& Ray, J. (2016). Global desires to migrate. Adjusting to a World in Motion: Trends in Global Migration and Migration Policy, 21-57.

Hazans, M. (2016). Migration experience of the Baltic countries in the context of economic crisis. In Labor migration, EU enlargement, and the great recession (pp. 297-344). Springer, Berlin, Heidelberg.

Hazans, M. (2019). Emigration from Latvia: a brief history and driving forces in the twentyfirst century. In The emigrant communities of Latvia (pp. 35-68). Springer, Cham.

Ikstens J. (2018). Ar balsi vien? in Aija Zobena (zin. red.). Apmaldījušies brīvībā: anomija mūsdienu Latvijā = Lost in Freedom: Anomy in Contemporary Latvia. Rīga: LU Akadēmiskais apgāds, 2018. 184 lpp.

Ivlevs, A. (2013). Minorities on the move? Assessing post-enlargement emigration intentions of Latvia's Russian speaking minority. The Annals of Regional Science, 51(1), 33-52.

Kaša, R., \& Mierina, I. (2019). The emigrant communities of Latvia: national identity, transnational belonging, and diaspora politics (p. 298). Springer Nature.

King, R., Lulle, A., Morosanu, L., \& Williams, A. (2016). International youth mobility and life transitions in Europe: Questions, definitions, typologies and theoretical approaches. University of Sussex, Sussex Centre for Migration Research WP Series 86

King, R., R. Skeldon. (2010). 'Mind the Gap!' Integrating Approaches to Internal and International Migration. Journal of Ethnic and Migration Studies, 36(10): 1619-1646

Kronenfeld, D. A. (2005). The effects of interethnic contact on ethnic identity: Evidence from Latvia, Post-Soviet Affairs, 21(3), 247-77.

Laitin, D. D. (1995. Identity in formation: the Russian-speaking nationality in the post-Soviet diaspora. European Journal of Sociology, 36(2), 281-316.

Latviešu valodas aǵentūra. (2020). Valodas situācija Latvijā 2016 - 2020. Retrieved from https://valoda.lv/petijumi/valodas-situacija-latvija-2016-2020/.

Linz, J. J. and Stepan, A. (1996). Problems of democratic transition and consolidation: Southern Europe, South America, and post-Communist Europe. London: Johns Hopkins University Press.

Lulle, A., \& Jurkane-Hobein, I. (2017). Strangers within? Russian-speakers’ migration from Latvia to London: A study in power geometry and intersectionality. Journal of Ethnic and Migration Studies, 43(4), 596-612.

McCollum, D., Apsite-Berina, E., Berzins, M., \& Krisjane, Z. (2017). Overcoming the crisis: the changing profile and trajectories of Latvian migrants. Journal of Ethnic and Migration Studies, 43(9), 1508-1525.

Melvin, N. (1995). Russians beyond Russia: The politics of national identity. London: The Royal Institute of International Affairs.

Migali, S., \& Scipioni, M. (2019). Who’s About to Leave? A Global Survey of Aspirations and Intentions to Migrate. International Migration, 57(5), 181-200.

Mintchev, V., Boshnakov, V., Richter, M., \& Ruspini, P. (2017). Determinants of Migration and Types of Migration and Mobility. In Migration and Transnationalism Between Switzerland and Bulgaria (pp. 25-60). Springer, Cham.

Milasi, S. (2020). What Drives Youth's Intention to Migrate Abroad? Evidence from International Survey Data. IZA Journal of Development and Migration, 11(1).

Muiznieks, N., Rozenvalds, J., and Birka, I. (2013). Ethnicity and social cohesion in the postSoviet Baltic states. Patterns of Prejudice, 47(3), 288-308. 
Varpina et al., 2021. Who is More Eager to Leave? Differences in Emigration Intentions Among

Latvian and Russian Speaking School Graduates in Latvia

Otrachshenko, V., \& Popova, O. (2014). Life (dis) satisfaction and the intention to migrate: Evidence from Central and Eastern Europe. The Journal of Socio-Economics, 48, 40-49.

Pisarenko, O. (2006). The acculturation modes of Russian speaking adolescents in Latvia: Perceived discrimination and knowledge of the Latvian language. Europe-Asia Studies, 58(5), 751-73.

Plopeanu, A. P., Homocianu, D., Florea, N., Ghiuță, O. A., \& Airinei, D. (2019). Comparative patterns of migration intentions: Evidence from eastern European students in economics from Romania and Republic of Moldova. Sustainability, 11(18), 4935.62.

Šūpule, I. (2007). Etniskās attiecības un akulturācijas procesi Latvijā: Iedzīvotāju attieksmes pret dažādām akulturācijas stratēgijām. Latvijas Universitātes Raksti, 714, 31-43.

Van Dalen, H. P., \& Henkens, K. (2012). Explaining low international labour mobility: the role of networks, personality, and perceived labour market opportunities. Population, Space and Place, 18(1), 31-44.

Van Mol, C. (2016). Migration aspirations of European youth in times of crisis. Journal of youth studies, 19(10), 1303-1320.

Veale, A., Dona, G. (2014). Child and Youth Migration. Mobility-in-migration in an era of Globalization. Palgrave Macmillan. London.

Vihalemm, T., Masso, A. (2003). Identity dynamics of Russian-speakers of Estonia in the transition period. Journal of Baltic Studies, 34(1), 92-116.

Williams, A. M., Jephcote, C., Janta, H., \& Li, G. (2018). The migration intentions of young adults in Europe: A comparative, multilevel analysis. Population, Space and Place, 24(1), e2123.

Zepa, B. (2006). The Changing Discourse of Minority Identities. Riga: BISS.

Zepa, B., Kḷave, E. (2011). In B. Zepa and E. Kḷave (Eds.), Latvia. Human Development Report 2010/2011: National Identity, Mobility and Capability, Riga: University of Latvia Press.

Zobena, A. (2018). Apmaldījušies brīvībā: anomija mūsdienu Latvijā. 


\section{PĒTİJUMI EKONOMIKAS UN VADĪBAS JOMĀ ILGTSPĒ ĒIGAI IZGLİTİBAI}

Research in Economics and Management for Sustainable Education 
